This is a self-archived version of an original article. This version may differ from the original in pagination and typographic details.

Author(s): Hartimo, Mirja

Title: Radical Besinnung in Formale und transzendentale Logik (1929)

Year: 2018

Version: Accepted version (Final draft)

Copyright: (C) Springer Science+Business Media B.V., part of Springer Nature 2018

Rights: In Copyright

Rights url: http://rightsstatements.org/page/lnC/1.0/?language=en

Please cite the original version:

Hartimo, M. (2018). Radical Besinnung in Formale und transzendentale Logik (1929). Husserl

Studies, 34(3), 247-266. https://doi.org/10.1007/s10743-018-9228-5 


\section{Radical Besinnung in Formale und transzendentale Logik (1929) ${ }^{1}$}

\section{This is a pre-print of an article published in Husserl Studies. The final authenticated version is available online at: https://doi.org/DOI: 10.1007/s10743- 018-9228-5}

ABSTRACT. This paper explicates Husserl's usage of what he calls 'radical Besinnung' in Formale und transzendentale Logik (1929, henceforth FTL). Husserl introduces radical Besinnung as his method in the introduction to FTL. Radical Besinnung aims at criticizing the practice of formal sciences by means of transcendental phenomenological clarification of its aims and presuppositions. By showing how Husserl applies this method to the history of formal sciences down to mathematicians' work in his time, the paper explains in detail the relationship between historical critical Besinnung and transcendental phenomenology. Ultimately the paper suggests that radical Besinnung should be viewed as a general methodological framework within which transcendental phenomenological descriptions are used to criticize historically given goaldirected practices.

KEYWORDS: Husserl, Formal and Transcendental Logic, Besinnung, mathematics, apophantic logic, phenomenological method, criticism.

\section{Introduction}

This paper explicates Husserl's usage of what he calls 'radical Besinnung' in Formale und transzendentale Logik (1929, henceforth FTL). Husserl started to emphasize the importance of Besinnung already in the early in the $1920{ }^{2},{ }^{2}$ but, for the sake of a clear argument, I limit myself

\footnotetext{
${ }^{1}$ This paper has been greatly improved thanks to the detailed criticisms and useful and generous suggestions of George Heffernan. I am particularly thankful for him for drawing my attention to FTL §§102-105, where Husserl discusses transcendental Selbst-Besinnung.

2 The term is mentioned already in Logical Investigations (e.g., Hua1/1, 24-25; 304). The number of references to it increases dramatically in Husserl's texts in 1922, starting with his London Lectures 1922 (Hua 35), Introduction to
} 
to Husserl's usage of it in FTL. FTL is, after all, according to Husserl's own assessment, his "most mature" work, even if "too concentrated" (Schuhmann 1977, 484-485).3

In the introduction to FTL, Husserl explicitly introduces and defines radical Besinnung as his method. While the role of this concept has gone largely unnoticed in the secondary literature, I will argue that it is of utmost importance for understanding Husserl's approach to the exact sciences in FTL. 4 It makes his approach a context-dependent, historically informed, and critical commentary on the work of the mathematicians in his time. It also helps to understand how Husserl's intentional history of the exact sciences disentangles the conflicting and overlapping goals within the tradition. Most importantly, it shows how Husserl's intentional history of the exact sciences and their transcendental examination combine to form a method that aims at clarification and even revision of the fundamental concepts of the formal sciences. I will then indicate how Husserl's usage of radical Besinnung in FTL presents it as a general framework within which the transcendental phenomenological descriptions are used to criticize historically given goal-directed practices. In the end I will briefly discuss how Husserl's Krisis also exemplifies this approach and how Husserl's usage of radical Besinnung explains the role of specifically transcendental phenomenology in his cultural criticism.

1. Radical Besinnung introduced and defined as a method

Philosophy Lectures 1922/1923 (Hua35), and the Kaizo articles from 1922-24 (Hua 27). Husserl also continues to expand on the notion in the 1930s and applies it in the practical sphere (e.g. Hua 42, where Husserl's emphasis is on "universal practical Besinnung"). So neither the scope nor the significance of Besinnung is restricted to FTL. I am here indebted to George Heffernan's hitherto unpublished "Concordance to Husserl's Use of the Term Besinnung".

${ }^{3}$ According to Schuhmann, Husserl related this to Grimme in a letter dated to May 31, 1937 (not included in the Briefwechsel). The original reads: "Ich mußte sie regelrecht studieren, ich fand sie schwer, aber war im Ganzen sehr zufrieden. Es ist doch mein reifstes Werk, nur zu sehr konzentriert" (Schuhmann 1977, 484-485).

4 The accounts that discuss Besinnung see it as a kind of existential self-meditation (esp., Dodd 2004, 30; Moran 2012, 49. See also Carr 1991 and Steinbock 1995). The present paper argues for it as a (third-personal) method, which aims at critical understanding of the aims and goals of communities and cultures. When applied to one's own culture, it may arguably yield the kind of existential significance emphasized by the previous commentators. Its existential significance is here regarded as following from the heightened understanding of the purposes of the activities and institutions - which is nevertheless the primary aim of Besinnung. Thus, even though the present paper does not address the existential significance of Besinnung, it is perfectly compatible with such emphases. 
In the introduction to Formale und transzendentale Logik Husserl first explains the importance of logic as a normative guide for the sciences as rational practices. According to Husserl, the core of this sense of logic has its origin in Plato's dialectic. This core has survived the subsequent development -despite the widely different presentations, caricatures and even "the chaos of modern logical efforts" (“das Durcheinander der modernen logischen Versuche”: FTL 12/8).5 For Husserl, logic and the sciences are cultural formations produced by the practice of the scientists through generations. This practice has a final sense, a goal-sense toward which the scientists have been continually striving (FTL, 13/9). Husserl's investigations into objective logic aim at unveiling the goal-sense of logic as a theory of science. This is connected to an insight that the goal-sense of mathematics is ultimately different from that of logic. Accordingly, mathematics has a separate, albeit intertwined, genesis when compared to logic as a theory of science.

The method for this endeavor is Besinnung, which Husserl defines as follows:

Besinnung signifies nothing but the attempt actually to produce the sense 'itself, ..., it is the attempt to convert the 'intentive sense' ... the sense 'vaguely floating before us' in our unclear aiming, into the fulfilled, the clear, sense, and thus to procure for it the evidence of its clear possibility (FTL, 9).

Besinnung besagt nichts anderes als Versuch der wirklichen Herstellung des Sinnes ,selbst', der in der bloßen Meinung gemeinter, vorausgesetzter ist; oder den Versuch, den ,intendierenden Sinn`, ... den im unklaren Abzielen ,vage vorschwebenden` in den

\footnotetext{
${ }^{5}$ References are either to paragraphs or to pages of FTL. They refer to paragraphs (preceded by the sign " $\S$ ") with the exception of the introduction to FTL, which does not have numbered paragraphs. In it, as well, in the case of quotations, the first page number is to the German original, the second to the English translation. I will provide the German original text in the main text or in footnotes depending on the importance and the length of the quotation. If the quotations are given in both languages, the page numbers are to the work in the language of the quotation.
} 
erfüllten Sinn, den klare überzuführen, ihm also die Evidenz der klaren Möglichkeit zu verschaffen (FTL, 13).

According to Husserl's elucidation of the concept, Besinnung means clarification of the sense of the activity by explication of the implicit goals that determine the activity. The term sense (Sinn) does not refer to a sentence meaning, but rather to a goal-sense [Zwecksinn] of the activity. The scientists are not necessarily aware of what exactly they are striving for and whether their goals are realizable. Explication of these goals makes it possible to criticize these goals and, for example, to estimate their practical realizability. Furthermore, Husserl specifies that finding out what the scientists are aiming at requires entering into "a community of empathy with the scientists" [Mit den Wissenschaftlern in Einfühlungsgemeinschaft stehend oder tretend] (FTL, 13/9). This suggests that the engagement with the scientists is necessary for gaining a correct understanding of their intentions.

Husserl was not only interested in a descriptive approach of discerning the goals of the sciences, but he also aimed at an evaluation of these goals. This results in what he terms "radical Besinnung":

Radical Besinnung, as such, is at the same time criticism for the sake of original clarification. Here original clarification means shaping the sense anew, not merely filling in a delineation that is already determinate and structurally articulated beforehand ... original sense-investigation [Besinnung] signifies a combination of determining more precisely the vague predelineation, distinguishing the prejudices that derive from associational overlappings, and cancelling those prejudices that conflict with the clear sense-fulfilment - in a word, then: critical discrimination between the genuine and the spurious (FTL, 10).

This reads in full in German as follows: 
Radikale Besinnung ist eo ipso zugleich Kritik, die ursprünglicher Klärung dient. Diese Klärung hat hier den Charakter einer neuen Sinngestaltung und nicht den einer bloßen Ausfüllung einer vorweg schon bestimmten und gegliederten Vorzeichnung. Eine derart ganz bestimmte Sinnesvorzeichnung ist ja überall und wesensmäßig nur möglich als eine sekundäre Folge einer schon gewonnenen Klarheit. Ist deren lebendige Evidenz verflossen, so verbleibt ihre habituelle Leistung, mit der Möglichkeit einer zunächst leeren Restitution, die dann in der Leergestalt die bestimmte Sinnesvorzeichnung enthält. Diese führt dann die Gewissheit möglicher klarer Restitution als Wiederholung der Evidenz mit sich. Ist, wie für uns, dieser Fall nicht in Frage, so bedeutet ursprüngliche Besinnung ineins Näherbestimmung der bloss vage unbestimmten Vorzeichnung, Abhebung der aus associativen Überschiebungen herstammenden Vorurteile, und Durchstreichung der mit der besinnlichen Erfüllung streitenden; also mit einem Wort Kritik der Echtheit und Unechtheit (FTL, 14).

As will become clear in what follows, in FTL the ultimate radicality of Besinnung is achieved through transcendental phenomenological investigations. In the context of FTL these are carried out in "transcendental logic" or "subjective logic" -the main theme of part II of the work. ${ }^{6}$ Transcendental logic clarifies the presuppositions and especially evidences striven at in formal sciences. This is what led Husserl to the novelty of FTL, i.e., to isolate pure logic of noncontradiction (to which belong formal mathematics and logic considered mathematically) from logic considered as a theory of science (FTL 16/12). The consequent distinction between the kinds of evidence is an example of the results obtained by radical Besinnung (I will explain this in more detail in section 3 below). Husserl's search for radicality, i.e., towards

\footnotetext{
${ }^{6}$ Transcendental logic refers to transcendental philosophical investigations of formal logic. In FTL Husserl does not explicitly use the phenomenological reduction as a way to transcendental phenomenology but rather employs 'the way through ontology' to transcendental phenomenology, as discussed by Iso Kern $(1976,141)$. This path is more piecemeal: In pursuit of "radicality," i.e., "uprooting all prejudices," it starts with the examination of the presuppositions of logic and ultimately leads to full-fledged transcendental Selbstbesinnung understood as transcendental phenomenology (§§104-105).
} 
presuppositionlessness, ultimately leads to transcendental Selbstbesinnung at the end of FTL $(\S \S 103-105) \cdot{ }^{7}$

Having mentioned first Besinnung and then radical Besinnung as indicated above, Husserl concludes: "So much by way of a most general characterization of the aim attempted and the method followed in this work. It is, accordingly, an intentional explication of the proper sense of formal logic” (FTL, 10). [“Dies zur allgemeinsten Charakteristik der in dieser Schrift versuchten Zielstellung und befolgten Methode. Es ist also eine intentionale Explikation des eigentlichen Sinnes der formalen Logik" (FTL, 14).] Therefore it is incontestable that Husserl introduces Besinnung, more precisely, radical Besinnung, as his method in FTL. Moreover, the deliberate adoption of Besinnung as a systematic method indicates that it involves much more than mere speculative musing on scientists' goals. To the contrary, it requires engagement with the people in question together with a conscious attempt at understanding them correctly. ${ }^{8}$

While Besinnung is the method used in FTL, the aim of the essay is correspondingly "an intentional explication of the proper sense of formal logic" [intentionale Explikation des eigentlichen Sinnes der formalen Logik] (FTL, 14/10). 'Intentional explication' refers to the philosopher's task of clarifying and renewing the goal-sense of logic towards which the scientists have been continually aiming. Husserl is thus examining the sense of logic by examining what the scientists and logicians have aimed at but not attained in their investigations. He aims to

\footnotetext{
${ }^{7}$ Note that Besinnung can be exercised in both, natural and transcendental, attitudes. Besinnung of the formal sciences in the first part of FTL is carried out in the natural attitude. Husserl discusses transcendental Besinnung in FTL only in the few fascinating passages towards the end (§§103- 105).

${ }^{8}$ Husserl describes the task of FTL to be "the clear theoretical explicating of the genuine sense of all science as such"(my emphasis, FTL, 9) [den echten Sinn von Wissenschaft überhaupt klarzulegen und in der Klarheit theoretisch zu explizieren" (my emphasis, FTL 14)]. In paragraph §104 Husserl accordingly refers to systematic Besinnungen concerning the world. Recall that in Ideas /I Husserl characterizes the theoretical attitude of the natural sciences (omnipresent in FTL) as having an active focus on what is objective (Ideas II, esp. §3. Cf. also The Crisis §36). I propose that Besinnung is a "human scientific" analogue to the natural theoretical attitude in that it involves an active attempt to understand people's intentions correctly.
} 
glean the ultimate goal of logic by studying the practice of science and logic. ${ }^{9}$ This necessitates looking at the intentional history of logic to discern the direction in which logic has been and still is developing. It also suggests that the essay is based on Husserl's empathetic engagement with the goals of the mathematicians and logicians around him. In the 1920s Husserl was not in Hilbert's Göttingen anymore, but rather in Freiburg, where his contacts with mathematicians were not as frequent as earlier in Göttingen..$^{10}$ In practice, in the 1920 , Husserl engaged in Besinnung of modern mathematics by reading some programmatic work by Hilbert and Hermann Weyl, and in conversations with his students (especially Friedrich Mahnke) and especially his assistant Oskar Becker. ${ }^{11}$

Note that by means of Besinnung Husserl approaches people's intentions, yet he is not examining his or their personal goals in life, nor is he engaged in trying to understand others' motivations. Rather, he establishes Besinnung as the activity of understanding the goals and aims of the practices of communities or groups, here scientists. ${ }^{12}$ Even if he focuses on some individual's, like Hilbert's, goals, he does so because he believes that they represent the goals of

\footnotetext{
${ }^{9}$ In focusing on practice, Husserl's approach anticipates many present-day approaches to the sciences (cf. Rouse 2002; Wimsatt 2007), but contrary to most of them, he looks at the practice of science as intentional goal-directed activity.

${ }^{10}$ Husserl moved from Göttingen to Freiburg in 1916 (Schuhmann 1977, 200).

${ }^{11}$ The marginalia in his personal copies show that Husserl read carefully Hilbert's "Neubegründung der Mathematik"(1922) and Weyl's "Die heutige Erkenntnislage in der Mathematik" (1925), as well as Weyl's subsequent book Philosophie der Mathematik und Naturwissenschaft (1926) (See Hartimo 2018). The letters exchanged between Mahnke and Husserl are involved and often concern mathematics. However, the letters also suggest that Mahnke got his inspiration from Husserl rather than the other way around. Becker was Husserl's assistant from 1923 until 1931 and presumably the most important figure in informing Husserl about the mathematical matters in the 1920s. Oskar Becker was the most knowledgeable in mathematics among the phenomenologists around Husserl (cf. Mancosu, 2010, 281). Ernst Zermelo, the set theorist, was also in Freiburg in the 1920s and 1930s, but there are no documents about the relationship between him and Husserl (except the oral report that Zermelo's late wife, Gertrude, has told Akihiro Kanamori that the two used to play chess together). 12 This distinguishes Besinnung from Selbstbestimmung, crucial to Husserl's lectures on ethics in the 1920s (cf. Hua 37, esp. pp. 161-167, where Selbstbestimmung is discussed in connection with "Selbstbestimmung des moralischen ich." Selbstbestimmung should not be confused with Selbstbesinnung, which is a species of Besinnung but so that the scope of the others includes also the investigator. Thus it is an examination of our intentional senses. Besinnung should also be distinguished from the (second-personal) understanding of other's motivations as elaborated especially in Ideen II.
} 
some community at large. In the case of Hilbert this seems well justified: Hilbert is generally viewed as a key figure in the development of the modern structural view of mathematics.

2. Intentional history and the final senses of the exact sciences

As promised in the introduction, Husserl's discussion of objective logic starts by examining the genesis of logic and sciences, from the ancients onwards, aiming to capture the final sense of these sciences. The intentional explication of logic is guided by a preliminary conception of the sense of logic. As Aristotle does (but contrary to his own procedure in The Crisis), Husserl derives his preliminary conception from the various significations of the word logos: speaking, thinking, and what is thought (FTL, §1). ${ }^{13}$ A summary of Husserl's theory of meaning follows, after which he proceeds to discuss the way in which logic is related to rationality. He first points out that logic does not extend to all reasoning and speech but is delimited to scientific reason, which is judgmental thinking [urteilendes Denken] that is "formed, ordered, connected, in certain manners - according to final ideas of reason” (FTL, §5, 26).${ }^{14}$ Husserl thus rules out everyday thought, talk, fiction and story-telling from the realm of logic. In contrast, logical formations have coherence (of theories and of systems) and they aim at truth. Husserl eventually narrows the concept of logic to logic as theory of science [Logik als

\footnotetext{
${ }^{13}$ In The Crisis Husserl does not discuss the various significations of the word logos to establish a preliminary starting point. Instead he holds that his method is necessarily circular: "Thus we find ourselves in a sort of circle. The understanding of the beginnings is to be gained fully only by starting with science as given in its present-day form, looking back at its development. But in the absence of an understanding of the beginnings the development is mute as a development of meaning. Thus we have no other choice than to proceed forward and backward in a zigzag pattern; the one must help the other in an interplay. Relative clarification on one side brings some elucidation on the other, which in turn casts light back on the former" (Crisis §9l, 58); "Wir stehen also in einer Art Zirkel. Das Verständnis der Anfänge ist voll nur zu gewinnen von der gegebenen Wissenschaft in ihrer heutigen Gestalt aus, in der Rückschau auf ihre Entwicklung. Aber ohne ein Verständnis der Anfänge ist diese Entwicklung als Sinnesentwicklung stumm. Es bleibt uns nichts anderes übrig: wir müssern im 'Zickzack' vor- und zurückgehen; im Wechselspiel muß eins dem andern helfen. Relative Klärung auf der einen Seite bringt einige Erhellung auf der anderen, die nun ihrerseits auf die Gegenseite zurückstrahlt" (Crisis, §9l, 59). In other words, instead of deriving his starting point from the various significations of the word logos, (as he does in FTL) he now thinks that the necessary starting point is in the present-day form of the sciences which then guides the historical investigation, which in turn helps understanding the present-day situation.

${ }^{14}$ In German, "in gewissen Weisen geformtes, geordnetes, verknüpftes, und zwar nach Zweckideen der Vernunft" (FTL, §5, 30).
} 
Wissenschaftslehre] (FTL, §5, 31/28). He then reminds the reader that logic does not intend to investigate the sciences as matters of fact, but intentionally, so that it makes clear the final ideas guiding the scientists (FTL, §5).15 In other words, logic is about what the scientists think they should aim at, i.e., what their normative ideals about the sciences are. Logic is also formal in the sense that it governs all materially determinate sciences with respect to their form (FTL, §6). Logic thus should explicate the implicit normative formal goals of the sciences that have governed the development of sciences throughout generations of scientists. Husserl is also explicit about the normative function that logic has - it is about the principles of pure reason:

The norms applied by logic are the principles of pure reason itself and the tests of rationality as such. Its formal cognitions are the standards for measuring the extent to which ostensible science conforms to the idea of genuine science, ... (FTL, §7, 31). ${ }^{16}$ Husserl also explains the two-sidedness of logic, i.e., that logic should include both objective formal logic and subjective transcendental logic. Including the subjective side of logic in the objective discipline makes the latter self-reflectively critical. The full importance of this will become clear below - after I have discussed the role of transcendental logic in radical Besinnung.

\footnotetext{
${ }^{15}$ Husserl's discussion of logic may sound odd to a contemporary reader. The reason for this is that for Husserl it is usually about structures and only derivatively about correct reasoning or proving. Accordingly Husserl discusses it by way of normative ideals (truth, consistency) aimed at. Referring to Scheler's distinction between normatives Sollen and ideales Sollen, Von Wright (1963) distinguishes between norms of what we ought to do or may or must not be done, and things that ought to or what may or must not be (1963, 13-14). Using von Wright's distinction one may say that Husserl's account of normativity of logic emphasizes the latter, i.e., how things ought to be. In contrast, the normativity of contemporary logic is typically understood to be about reasoning, and hence it is viewed in deontological terms, and it falls into von Wright's former category. Normativity of Husserl's logic requires a closer treatment than what is possible in the present paper. Suffice it to say that it is yet another aspect of Husserl's approach to logic that cannot be understood without a proper grasp of Besinnung as Husserl's method.

16 “Sie [die Logik] normiert aus den Prinzipien der reinen Vernunft selbst und normiert die Vernünftigkeit als solche. An ihren formalen Erkenntnissen ist zu messen, inwieweit prätendierte Wissenschaft der Idee der echten Wissenschaft gemäß ist, ..." (FTL, §7, 35)
} 
Thus armed with a preliminary understanding of the sense of logic, Husserl launches into his examination of the intentional history of logic. This takes place in two strands of argumentation: on the one hand there is the development of logic as the theory of judgments, i.e., apophantic logic, and on the other hand there is the development of formal mathematics. Common to these two fields is that they are both "interested specifically in certain derivative formations of anything-whatever” (FTL, §24), i.e., they are both formal.

The guiding concept for logic as a theory of judgment (i.e., apophantics) is truth. A closer inspection shows that truth presupposes non-contradiction (distinctness) and grammaticality. Grammaticality is defined by pure logical grammar, or "the theory of pure forms," as Husserl also calls it. Pure logical grammar is a theory in which one can define all possible judgment constructions out of few fundamental forms. For example, from the judgment ' $\mathrm{S}$ is p' one can construe the form 'Sp is q' and then ' $(\mathrm{Sp}) \mathrm{q}$ is $\mathrm{r}$ '. These judgments can be modified so that they can occur as component parts in, e.g., a conjunction or a hypothetical form of judgments. Such construction is law-governed and reiterative (FTL §13c).

The logic of non-contradiction is distinguished from pure logical grammar. The logic of noncontradiction defines what is valid. It is "pure apophantic analytics," to which belong the whole of syllogistics, but also much more, such as "formal-mathematical 'analysis"' (FTL, §14). Roughly, it consists of mathematics and logic in so far as the latter is considered mathematically. The third level is the logic of truth, which is about judgments in so far as they can be true. It is thus about the soundness of the judgments. Corresponding to the three levels of logic-pure logical grammar, non-contradiction, and truth -there are three different evidences: evidence in the most general sense, [Evidenz im weitesten Sinne], distinctness [Deutlichkeit], and clarity [Klarheit] (For details, see Heffernan 1989, esp. §7, 144-153).

While logic is directed at truth, the sense guiding formal mathematics is the Euclidean ideal, concretely captured by the notion of "definite manifold” (FTL, §31). The definite manifold is a 
structure derived from a Euclidean axiom system by means of "formalization." It is complete in the sense that it captures its domain exhaustively ("there is no truth about such a province that is not deductively included in the 'fundamental laws' of the corresponding nomological science”), as what Hilbert sought to capture with his 'axiom of completeness' (FTL, §31). ${ }^{17}$ Note how Husserl exercises radical Besinnung on Hilbert's goals in mathematics, that is, he explicates and further improves Hilbert's view as captured by the so-called axiom of completeness around the turn of the century. ${ }^{18}$

Thus on Husserl's analysis in FTL the final sense of logic is what Hilbert aspired to already around the turn of the century, that is, complete axiomatic theories. Husserl also refers to Riemann "and his successors," whom he credits to have taken the abstraction even further so that they take such system-forms, i.e., the definite manifolds, as mathematical objects, and thus to alter them freely, universalize them mathematically, and particularize the universalities - not, however, by obeying the rules for differentiating the species of a genus according to the Aristotelian tradition (such a differentiating being meaningless

\footnotetext{
${ }^{17}$ What exactly Husserl means by the notion of 'definite manifold' has been intensely debated in the secondary literature (see Hartimo 2016). In my view Husserl intends to capture with it categorical and syntactically complete theories (which in the light of the subsequent development of mathematical logic is usually not possible, even if desirable). Categoricity is a property of a theory, whose all realizations (in Husserl's case for example vectors, natural numbers, etc. ) are isomorphic to each other (i.e., there is a one-to-one correlation between individuals and relations of one domain with the individuals and relations of another domain) so that the theory defines a unique formal model "up to isomorphism." A syntactically complete theory is a theory in which every sentence or its negation of the language of the theory can be deduced from the axioms of the theory.

${ }^{18}$ Husserl is explicit about this in FTL: "Without being guided by the philosophico-logical considerations that determined my studies, Hilbert arrived at his concept of completeness (naturally quite independently of my stillunpublished investigations); he attempts, in particular, to complete a system of axioms by adding a separate 'axiom of completeness'. The above-given analyses should make it evident that, even if the inmost motives that guided him mathematically were inexplicit, they tended essentially in the same direction as those that determined the concept of the definite manifold" (FTL, §31). In this connection Husserl refers to the work on definiteness that he carried out almost thirty years earlier. He is thus either reinterpreting his own earlier approach or else claiming that he used Besinnung already then, even if only implicitly.
} 
here), but rather in conformity with the superordinations and subordinations that present themselves in the province of the formal (FTL, §30, 93). ${ }^{19}$

Riemann's successors referred to here seem not to be geometers or physicists, but rather set theorists or model-theorists. Einstein based his general theory of relativity on Riemannian geometry, but this does not seem to be what Husserl had in his mind. In his reference to Riemann, Husserl is primarily interested in the development of pure mathematics, not physical geometry. Ultimately Husserl intends a theory, "which would comprise all possible forms of theories (correlatively, all possible forms of multiplicities) as mathematical particularizations accordingly, as deducible" (FTL, §32, 98). ${ }^{20}$ Husserl thinks that mathematical reality ideally consists of the axiomatic theories that define abstract theory forms (i.e., structures) unambiguously and uniquely. This is the modern view of mathematics as a study of structures (instead of, say, numbers). ${ }^{21}$ Indeed, on this point, Husserl's view is in line with the prevailing conception of modern mathematics. The view is well captured by Weyl, who refers to Husserl's view expressed in the Prolegomena, to which Husserl himself, too, refers in FTL:

Pure mathematics, in the modern view, amounts to a general hypothetico-deductive theory of relations; it develops the theory of logical 'molds' without binding itself to one or the other among the possible concrete interpretations. Concerning this formalization, as "a point of view, without which an understanding of mathematical methods is out of the question,” compare Husserl, Logische Untersuchungen, I, Sections 67-72. “... The axioms become implicit definitions of the basic concepts occurring in them. The concepts, admittedly, retain a certain range of indeterminacy; but the logical

\footnotetext{
19 "sie frei zu wandeln, sie mathematisch zu verallgemeinern und die Allgemeinheiten zu besondern; das aber nicht in Bindung an die hier bedeutungslosen Differenzierungen nach Gattung und Art im Sinne der Aristotelischen Tradition, sondern im Sinne der im Gebiet des Formalen sich darbietenden formal-mathematischen 'Uber- und Unterordnungen" (FTL, §30, 97).

20 "die alle möglichen Theorienformen bzw. Alle möglichen Mannigfaltigkeitsformen als mathematische Besonderungen also ableitbar, in sich fassen würde" (FTL, §32, 102).

${ }^{21}$ This view of mathematics is further elaborated in Da Silva $(2017,185-215)$.
} 
consequences of the axioms are valid, no matter what concrete interpretation may be adopted within this range. Pure mathematics acknowledges but one condition for truth, and that an irremissible one, namely consistency (Weyl 2009 [1949], 27).

Pure mathematics and apophantic analytics are both about something that is universal and a priori. Both are thus formal disciplines and initially it seems that they are equivalent, correlated disciplines. While pure mathematics is about formal objects in general, the theory of judgment is about judgments about the objects (ibid., §42). However, Husserl's Besinnung shows them to have different final senses. Apophantic logic is guided by the goal of truth, that is, attaining verification by the facts themselves and how they actually are. Scientific judgments in particular aim at truths in a sense of correct critically verified judgments (ibid., §46). In other words they aim at being fulfilled by the evidence of having the object in front of us. Mathematicians, in turn, "need not be at all concerned with the fact that there actually are multiplicities in concrete ‘actuality”' (ibid., §51), since pure mathematics does not care whether its theories are concretely realized (ibid., §51). Hence, for

a 'pure' formal mathematics, there can be no cognitional considerations other than those of 'non-contradiction', of immediate or mediate analytic consequence or inconsistency which manifestly include all questions of mathematical 'existence'... One must see that a formal mathematics, reduced to the above-described purity, has its own legitimacy and that, for mathematics, there is in any case no necessity to go beyond that purity” (FTL, §52, 145/140).

The mathematician can adopt the "logical function" (FTL, §76), i.e., strive at truth in two ways: either through the material applications such as geometry or exact physics, ${ }^{22}$ or else by means of

\footnotetext{
22 This is what the applications in da Silva's Mathematics and Its Applications (2017) refer to. In it Da Silva gives the most profound explanation that I am aware of how Husserl's view of mathematics becomes applied in physics.
} 
apophantic analytics. ${ }^{23}$ Apophantic analytics differs from formal mathematics in being constructive so that in it more complex judgments are constructed from the elementary judgments. When the theme of truth is brought into formal mathematics, a task arises to "prove" the formal structures of mathematics with the apophantic logic. In apophantic logic complex judgments are constructed so that the evidence that has its origin ultimately in perception is brought to higher flights of mathematics. Apophantics is thus able to transmit the evidence related to perception of concrete individuals to the more abstract constructions (FTL, §84). It is thus able to provide the complex judgments a sense genesis, which can be traced back to its “canonical" elements. The origin of the evidence in elementary judgments and especially judgements of perception motivates the further need to clarify the origin of judgments in the posthumously published Erfahrung und Urteil.

Husserl's apophantic logic thus functions much like Hilbert's proof-theory, which seeks to prove the consistency of mathematics and to give certainty to mathematics by basing mathematics on intuition of strokes. While Hilbert's proof theory aims at both consistency and truth at the same time, Husserl carefully separates these two goals. Accordingly, he thinks that apophantic logic is not needed for formal mathematics; hence it is not needed to establish its consistency. Its function is philosophical, not mathematical (cf. FTL §§51, 82). ${ }^{24}$ In particular, it shows how

\footnotetext{
${ }^{23}$ Apophantic analysis resembles Weyl's predicative and Hilbert's proof-theoretical attempts to provide mathematics secure foundations.

${ }^{24}$ In his "Neubegründung der Mathematik"(1922) read and marked by Husserl, Hilbert writes in a passage marked by Husserl, that as a precondition for the application of logic there must already be given in representation "extralogical discrete objects, which exist intuitively as immediate experience before all thought. If logical inference is to be certain, then these objects must be capable of being completely surveyed in all their parts" (Hilbert 1922, 163/Ewald 1996, 1121). For Hilbert, sets of strokes, such as III and IIII, provided such an intuitive foundation. Husserl obviously thinks that the "extra-logical discrete objects" should be objects of ordinary perception, not strikes as what Hilbert suggests. This criticism of Hilbert is also put forward by Dietrich Mahnke (1922). All this, i.e., the difference between formal mathematics aiming at distinctness and truth-logic aiming at truth, and the reliance on the perception of individuals is captured in the following words by Husserl: "For mathesis universalis, as formal mathematics, these ultimates have no particular interest. Quite the contrary for truth-logic: because ultimate substrate-objects are individuals, about which very much can be said in formal truth, and back to which all truth ultimately relates. If one keeps to the formal of pure analytics, if the evidence - the evidence serving this discipline - accordingly relates only to pure judgment-senses as distinct, one cannot establish this last proposition; it is by no means an 'analytic' proposition. To have insight into it, one must make ultimate cores intuited, on must draw
} 
evidence can be transmitted to the more abstract reaches of the formal sciences, and hence it enables relating them to truth.

Husserl's Besinnung of the formal sciences thus disentangles different kinds of aims from one other in the foundations of mathematics in the 1920s. In his Mathematische Existenz (1927), Oskar Becker uses Husserl's distinction between non-contradiction and truth to distinguish between formalists and intuitionists: while formalists (i.e., Hilbert and others) aim at consequence (non-contradiction), intuitionists (Brouwer) aim at truth; and while for the formalists the notion of existence relies on non-contradictoriness, the intuitionists' notion relies on constructability (Becker 1973, 29-30, 69). ${ }^{25}$

All in all, Husserl's theses about formal logic and mathematics are impossible to understand unless they are understood as results of Besinnung, as historically informed clarifications of the intended but entangled goal-senses of the mathematicians and logicians in Husserl's time. In particular, the novelty of FTL, Husserl's distinction between mathematics (and mathematical logic) and logic (and applied mathematics) cannot be otherwise understood: these disciplines are ultimately distinguished only by their different "intentional senses," i.e., the goals striven for in them, and hence the distinction requires prior Besinnung of these disciplines.

Husserl's engagement in Besinnung of the mathematicians of his time shows also in the way he marked the books he read. The markings show that his interest in the mathematicians' work is in their goals and aims, never in the technical details, which he left for the mathematicians to

\footnotetext{
fullness of adequation, not from evidence of the judgment-senses, but instead from evidence of the 'matters' or 'affairs' corresponding to them” (FTL, §82, 203). For more on Husserl's relationship to Hilbert, see Hartimo (2017).

${ }^{25}$ Becker was at the time Husserl's assistant and has written a part of the appendix III of FTL. Becker explicitly claims that in distinguishing truth from consequence he is indebted to Husserl $(1973,4)$. Becker's subsequent philosophical consideration of mathematical existence then decides the dispute between formalists and intuitionists in favor of intuitionism and its "contentful" mathematics, "which alone discovers real phenomena that are accessible to originary and adequate intuition and capable of an existential interpretation" $(1973,2)$. Husserl probably would not go as far as Becker in interpreting Hilbert's mathematics as examining mere consequence, but he presumably would claim that Hilbert does not clearly distinguish between the two goals striven at in formal sciences: truth and non-contradiction.
} 
worry about (Hartimo 2018). Likewise, looking for a mathematically developed theory in Husserl's later writings is bound to be disappointing. ${ }^{26}$ Rather, the virtue of Husserl's discussions of mathematics and logic lies in their evaluation of the goals that the formal scientists are aiming at, i.e., something that is often entirely neglected by the formal scientists.

\section{Transcendental logic and radical Besinnung}

Transcendental logic examines how formal logic is related to subjectivity. It shows that in aiming at evidence the scientists strive to have a correct representation of reality. As Husserl points out, however, all evidences are fallible (FTL §58). The search for evidence makes our consciousness teleological, it gives it

a pointedness toward 'reason' and even a pervasive tendency toward it - that is: toward the discovery of correctness (and, at the same time, toward the lasting acquisition of correctness) and toward the cancelling of incorrectnesses (thereby ending their acceptance as acquired possessions) (FTL, §60, 160).27

The tendency to reason in turn gives a rise to intention-fulfilment structure towards fulfilling evidence:

As in every other acting the ends of our action, the new judgments to be produced, are consciously intended to by us beforehand in modes of an anticipation which is empty, still undetermined in respect of content, or in any case still unfulfilled; we are consciousness of them thus as the things toward which we are striving and the bringing

\footnotetext{
${ }^{26}$ Nevertheless, surprisingly much can be found in Husserl's formal writings, cf. a recent and very thorough explanation of Husserl's logic by Ansten Klev (2017).

27 "ein Angelegtsein auf 'Vernunft' und sogar eine durchgehende Tendenz dahin, also auf Ausweisung der Richtigkeit (und dann zugleich auf habituellen Erwerb derselben) und auf Durchstreichung der Unrichtigkeiten (womit sie aufhören als erworbener Besitz zu gelten)" (FTL, §60, 169).
} 
of which to an actualizing self-givenness makes up the action, as accomplished step by step. (FTL, $§ 63,167)^{28}$

Indeed, in Husserl's view of mathematics and logic, scientists may strive at three different kinds of evidences (evidence in the broadest sense, distinctness, and clarity), and accordingly there are three different modes of empty intention and fulfilling intuition (FTL, §70a).

The constitutive criticism will also uncover idealizing presuppositions of mathematics and logic. Pure mathematics, for example, presupposes the ideal identity of its formations so that they are assumed to be available to us at all times. Transcendental logic examines their peculiarly transcendent givenness (FTL, §73). Another presupposition to be revealed is the recursive 'and so forth.' Its subjective correlate is "one can always again". According to Husserl, "[t]his is plainly an idealization, since de facto no one can always again” (FTL, §74, 196/188). ${ }^{29}$ But it is important, not only thanks to (countable) infinite senses (e.g., the series of natural numbers), but also to what Husserl calls "constructional infinites" (presumably he means the uncountable cardinalities):

Obviously we have here a repetition of the problem concerning subjective constitutive origins: as the hidden method of constructions which is to be uncovered and reshaped as a norm, the method by which 'and so forth', in various senses, and infinities as categorial formations of a new sort become evident... Precisely this evidence, in all its particular formations, must now become a theme (FTL, §74, 189).30

\footnotetext{
28 "Wie bei allem Handeln sind die Handlungsziele, die zu erzeugenden neuen Urteile im voraus in Modi einer leeren, inhaltlich noch unbestimmten und jedenfalls noch unerfüllten Antizipation uns bewußt, als das, worauf wir hinstreben und was zur verwirklichenden Selbstgegebenheit zu bringen, eben das sich schrittweise vollendende Handeln ausmacht." (FTL, §63, 176).

29 "Es ist eine offenbare Idealisierung, da de facto niemand immer wieder kann" (FTL, §74, 196).

30 "Offenbar wiederholt sich hier das Problem der subjektiven konstitutiven Ursprünge als der verborgenen, zu enthüllenden und als Norm neu zu gestaltenden Methode der Konstruktionen, der Methode, in der das 'und so weiter' verschiedenen Sinnes und die Unendlichkeiten als neuartige kategoriale Gebilde ... evident werden. Eben diese Evidenz in allen ihren Sondergestalten muß nun aber zum Thema werden" (FTL, §74, 196).
} 
This passage is important because it shows that Husserl envisions yet further kinds of evidence (than the above discussed evidence in the broadest sense, distinctness and clarity) and that Husserl's approach is open to possible new developments and new kinds of evidences sought for in them. Husserl's transcendental logic thus shows that the practice of logic and mathematics has plural aims and plural evidences that have to be sorted out and clarified. The whole first chapter of Part II of FTL is about evidence because Husserl has now turned to examine the selfgivenness of logical and mathematical formations and operations.

Transcendental logic reveals that in practice scientists are not always clear about what they are doing, and "internal shiftings of intentionality" may lead to equivocations (FTL, §70a):

Every productive doing involves intention and actualization. One can consider this doing itself and what it involves, and assure oneself of the identity between its purpose and the actualization that fulfils its purpose. In naïve intending and doing, the aiming can shift, as it can in a naïve repetition of that activity and in any other going back to something previously striven for and attained. Turning reflectively from the only themes given straightforwardly (which may become importantly shifted) to the activity constituting them with its aiming and fulfilment - the activity that is hidden ... throughout the naïve doing and only now becomes a theme in its own right - we examine that activity after the fact. That is to say, we examine the evidence awakened by our reflection, we ask it what it was aiming at and what it acquired; and, in the evidence belonging to a higher level, we identify and fix, or we trace, the possible variations owing to vacillations of theme that had previously gone unnoticed, and distinguish the corresponding aimings and actualizations, - in other words, the shifting processes of forming concepts that pertain to $\operatorname{logic}(\mathrm{FTL}, \S 69,177) 3^{31}$

\footnotetext{
31 "in jedem leistenden Tun liegt Intention und Verwirklichung; man kann dieses Tun und was darin liegt selbst betrachten, sich der Identität seines Absehens und der es erfüllenden Verwirklichung versichern. Im naiven
} 
To put this succinctly, the problem is that scientists' (or mathematicians') aimings can shift and their activities may thus fail to realize their goals. Or sometimes, as arguably in the case of Hilbert, they may be striving at more than one goal at once. In transcendental logic these activities are reflected upon and the problematic shiftings are identified and fixed. By means of the above described reflective examinations such equivocations can be removed (FTL, §70a). Indeed, Husserl explains that transcendental logic has a critical aim: it demands that evidence ...should be reflectively considered, reshaped, analyzed, purified, and improved; and that afterwards it can be, and ought to be, taken as an exemplary pattern, a norm (FTL, $\S 69,176) .3^{2}$

Since the clarified and revised evidences should eventually be adopted as norms (to be sure, ideal norms, not deontological norms, cf. footnote 15 above), transcendental logic aims at sorting out and even revising different normative aims that mathematicians and logicians may have. The clarification and revision of the normative aims, i.e., the evidences sought for, should ultimately lead to a revision of the fundamental concepts of the sciences. Thus, the transcendental investigations are fundamentally about

uncovering and criticism of the original logical method; and indeed we can characterize them all likewise as explorations of the method by which the 'fundamental concepts' of

\footnotetext{
Absehen und Tun kann sich die Zielung verschieben, und ebenso in der naiven Wiederholung und im sonstigen Rückgang auf das vorher Erstrebte und Erzielte. So auch in der im Zusammenhang der naiven Aktionen des Logikers verlaufenden Thematisierung. In der Reflexion von den geradehin allein gegebenen Themen (den sich evtl, sehr wesentlich verschiebenden) auf die sie in Abzielung und Erfüllung konstituierende Aktivität - die vordem im naiven Tun verborgen, oder wie wir auch sagen können, „anonym” bleibt und erst jetzt zum eigenen Thema wird - befragen wir hinterher die betreffende Aktivität. Das heißt, wir befragen die eben damit aufgeweckte Evidenz nach dem, worauf sie zielt und was sie erworben hat, und in der Evidenz höherer Stufe identifizieren und fixieren wir bzw. verfolgen wir die möglichen Abwandlungen sonst unmerklicher thematischer Schwankungen und unterscheiden wir die zugehörigen Zielungen und Verwirklichungen, mit anderen Worten, die sich verschiebenden logischen Begriffsbildungen" (FTL, §69, 184-185).

32 In German, "daß diese Evidenz - daß Evidenz überhaupt - reflektiv zu betrachten, zu analysieren, umzugestalten, zu reinigen und zu bessern ist und daß sie dann evtl. zum Muster, zur Norm genommen werden kann und genommen werden soll"' (FTL, §69, 184).
} 
analytics are produced originaliter, in that evidence which assures us of their respective essences as identical and safeguarded against all shiftings (FTL, §7ob, 180).33

Transcendental logic is thus needed for finding, revising, and justifying the basic concepts of the formal sciences. This criticism results in a "concomitant fixing of terminology" so that the concepts will persist "as acquisitions in the realm of habit" (FTL, §70b). The ultimate aim of radical Besinnung is that the revised concepts will be habitually used in scientific practices. This is the way in which philosophy is supposed to guide the sciences; it is the way in which logic is supposed to be the normative guide for the sciences as rational practices, as stated in the introduction to FTL. Accordingly, Husserl's aim in FTL in the end is to establish a method for revision of scientific practices.

The distinction between the logic of non-contradiction and the logic of truth discussed above is Husserl's concrete suggestion for such a revision in the practice of mathematics. In the introduction to FTL Husserl reveals that he was led to it through a problem of evidence, namely "the problem of the evidence of the sciences making up formal mathematics" (FTL, 12). In other words, he was led to it by examining the distinctness aimed at by the mathematicians as distinguished from clarity aimed at by the logicians. The sense-genesis, given by apodictic logic, shows that ultimately every conceivable judgment is related to individual objects. The evidence of clarity derives from the perceived objects themselves (esp. FTL §§82-86). However, "[f]or mathesis universalis, as formal mathematics, these ultimates have no particular interest" (FTL $\S 82,211 / 203$, also §87). Husserl's analysis shows that the source for distinctness lies elsewhere: ultimately it is found in the harmonious unity of possible experience, in which the contents of judgments have coherence of the matters in the synthetic unity of experience [der synthetischen

\footnotetext{
33 “Alle diese Untersuchungen haben den Charakter von fundamentalen der Enthüllung und Kritik der ursprünglichen logischen Methode, und zwar können wir sie alle auch bezeichnen als Erforschungen der Methode, durch die die „Grundbegriffe” der Analytik ursprünglich erzeugt werden in der jenigen Evidenz, die uns ihres identischen und vor allen Verschiebungen gesicherten Wesens versichert"(FTL, §70b, 188).
} 
Einheit der Erfahrung], also referred to as a universe of possible experience [ein Universum möglicher Erfahrung], or a unitary sphere of experience [ein einheitliche Erfahrungssphäre, ein einheitliches sachliches Gebiet] (§§89b, 91). I have elsewhere suggested that Husserl has in mind a model with which to establish the consistency and the independence of the axioms (as Hilbert did for geometry already around the turn of the century) (Hartimo 2017). In other words, Husserl's transcendental examination of evidences thus led him to distinguish between (model theoretical) distinctness and (proof-theoretical, constructive) clarity as two separate norms for the exact sciences.

4 The sense of mathematics and logic in FTL

Before proceeding, let me summarize Husserl's complex approach to the exact sciences: $\mathrm{He}$ starts with the intentional history of mathematics and logic that culminates respectively in Hilbert's axiomatic approach, and, in logic, in Husserl's view of three-level apophantic logic. This gives Husserl a historically informed conception of the goal-senses that mathematicians and logicians aim at. Whereas the former aim at non-contradiction, the latter aim at truth (with the specifications explained above).

For Husserl, the most important exact scientist was Hilbert, who was a central figure in shaping modern mathematics. For Husserl, Hilbert was the representative of the development of modern mathematics, a "Galileo" of modern mathematics. With his axiomatic approach Hilbert managed to explicate, to refine and thus to restate normative ideals of modern mathematics. In other words, his aims and goals point to the goal-sense of modern mathematics, towards which modern mathematics is developing. Accordingly, Husserl thinks that mathematical reality ideally consists of the abstract theory forms (i.e., structures). The evidence associated with such formal mathematics is distinctness [Deutlichkeit]. Furthermore, evidence of distinctness is all that the mathematicians need; they do not have to prove their theories with the apophantic analytics. Evidence of distinctness has its origin in a "unity of a sphere of experience," which 
appears to be Husserl's analysis of a model; the existence of a model that realizes a theory shows it to be consistent. All this can be understood as an analysis of mathematics as practiced in the early decades of the $20^{\text {th }}$ century.

Whereas mathematics is governed by the norm of distinctness, logicians aim at truth, which is related to another kind of evidence. Hilbert's proof theory (developed in the 1920s) appeared to strive for something like this, too. According to Husserl, logicians aim at fulfilment with clear [klar] evidence, which gives the objects "in originary intuition" analogously to ordinary perceived objects (Hilbert talked analogously about intuition of strokes). Husserl explains that if truth is taken as the guiding ideal then the abstract theory-forms should be able to obtain fullness by confronting extra-mathematical reality. This may take place by applying structures to material spheres, as is done in geometry and physics, or by constructing "analytics" in which judgments are constructed iterationally (recursively) out of elementary judgments about individual objects. Whatever is constructed in such an analytics is reducible to the simple judgments of individual objects and thus "proven." This explains how the evidence of the givenness of the objects of perception may be transferred to ever more abstract formations.

Regarded transcendentally, Husserl's picture of mathematics looks as follows: Thanks to the "teleology of reason" mathematicians and logicians seek evidence. They construct theories that they think could be fulfilled by evidence. This evidence is of different kinds. Mathematicians aim at distinctness, and logicians, in addition, at clarity. Moreover, Husserl hints at further distinctions between different kinds of evidences that are related to different kinds of iteration and e.g., different infinite cardinalities. After purification and amelioration these evidences can be adopted as norms guiding mathematics and science. Husserl's view is revisionist and it explicitly aims at changing the habits and customs of the practice so that they would conform to the clarified views of goals, viewed as guiding norms. Formal and Transcendental Logic can thus be read as Husserl's attempt to clarify, sort out, and revise the goals of mathematicians and 
logicians. Husserl's criticism is not mathematical, based on inspection of mathematicians' proofs and their correctness, but it is focused on the goal-senses identified in the mathematicians' work. Hence it can only be understood as an intentional explication of the aims of the exact scientists - in other words, it only makes sense as a result of Besinnung of the living intentions of the logicians, such as Hilbert.

The role of transcendental phenomenology is crucial for the critique aimed at in radical Besinnung. Transcendental logic reveals and clarifies the evidences that the mathematicians aim at. This leads to exposing all kinds of presuppositions assumed in these practices. Whereas much of FTL is focused on logic as theory, in the last chapter of FTL Husserl raises the question concerning how a theory of logical reason is possible (§101). Examining this question takes Husserl to all-encompassing transcendental phenomenology; his answer to the question is that it is "possible as a phenomenology of logical reason, within the frame of transcendental phenomenology as a whole" (§101, 274/267-268). This entails that the transcendental subjectivity engages in Selbstbesinnung, i.e., in transcendental Selbstbesinnung (§104). FTL thus starts with "natural" Besinnung to examine the "living intentions of the logicians." In the search for presuppositionlessness, Besinnung eventually "takes on the form of transcendental intersubjective Besinnung” $(\$ 104,276) .34$ Within it the transcendent world, including the sciences, become understood and ultimately phenomenology "understands itself as a reflective functional activity in transcendental intersubjectivity" (§ 104, 275). Thanks to ensuing Selbstbesinnung, the phenomenologist is in the world that includes not only co-existing absolute subjects, but also subjects who work together towards common goals (§104).

\footnotetext{
${ }^{34}$ The whole passage in German is as follows: "Es ist also wirklich nur Selbstbesinnung, aber nicht vorschnell abbrechende und in naïve Positivität umschlagende, sondern in absoluter Konsequenz eben das bleibend, womit sie anfing: Selbstbesinnung. Nur da $\beta$, sie ohne ihren Stil wesentlich zu ändern, im Fortschreiten die Form der transzendental-intersubjektiven annimmt" (FTL, §104, 282).
} 


\section{Besinnung in The Crisis}

Besinnung, and its various derivatives, frequent Husserl's subsequent texts and merit a closer examination than what is possible to engage in here. I however cannot resist the temptation of entering into a brief discussion about The Crisis. Indeed, Husserl claims already in the introduction to FTL that the present condition of European sciences is what necessitates radical Besinnungen (FTL, 9/5). In The Crisis Husserl engages in Rückbesinnung, i.e., Besinnung of the goals of the previous philosophers, to distill what was always sought for in philosophy, that is the "core" that points to the goal-sense of philosophy, towards which philosophy has always been striving (Crisis, §7). As in FTL with respect to logic, in The Crisis, in Husserl's words, “[w]e are attempting to elicit and understand the unity running through all the [philosophical] projects of history that oppose one another and work together in their changing forms" (Crisis, §15). Husserl engages in Selbstbesinnung placing himself within the nexus of intentional history of transcendental philosophers. Instead of uncovering the goal-senses of exact sciences as in FTL, The Crisis contains historical and critical Rückbesinnungen concerning the sciences in general. It is not reflection on Husserl's own personal goals in life, but it is about the goals of his (European) contemporaries and their predecessors.

Whereas in FTL Husserl distinguished between the goal-senses of mathematics and logic, in The Crisis Husserl distinguishes the goal-sense of modern science in contrast to the goal-sense of transcendental philosophy, i.e., objectivism as opposed to transcendentalism. In both of these strands, the history consists of accomplishments of individual people who work towards realizing certain (normative) goals. People mainly inherit their projects from their predecessors, but every now and then there are visionaries who redefine and reformulate these goals. In The Crisis, Galileo is Husserl' prime example of such a visionary. Galileo redefined the goals of modern sciences with his vision of a mathematization of nature. He managed to make a "restatement" [Wiederstiftung] of the normative goals that human beings work for in the 
sciences and that give their projects their goal-sense. The history of transcendental philosophy, in turn, is a nexus of a series of such geniuses: Husserl mentions Descartes, Locke, Hume, and Kant, who established the guiding ideal of the "transcendental." The achievements of these philosophers point towards the final sense of transcendental philosophy, as realized in Husserl's own transcendental phenomenology, as distinguished from psychology.

The entire investigation is carried out within the methodological framework of radical Besinnung, in which historical and transcendental Besinnung converge. Within it the goal sense of one strand, transcendental phenomenology, is used to criticize the goal-sense of the other strand, scientific rationality. 35 Transcendental phenomenology enables purifying and clarifying the concepts and presuppositions of the sciences. Practicing transcendental phenomenological clarification of, e.g., the essence of human being, or uncovering the presuppositions of the scientific enterprise, Husserl uses, in radical Besinnung, transcendental phenomenology to criticize the sense of modern rationality and the way it has been applied. Thus the role of the phenomenologist is not only to describe but also to identify the essential structures for the purpose of radical Besinnung, for the purpose of critically reflecting on what is going on in the society, and further, to suggest revisions for it. The need for such radical Besinnungen is not an academic matter but urgently demanded by the condition of humankind, as Husserl puts it in the introduction to FTL:

The present condition of European sciences necessitates radical Besinnungen. At bottom these sciences have lost their great belief in themselves, in their absolute significance. The modern man of today, unlike the ‘modern' man of the Enlightenment, does not behold in science, and in the new culture by means of science, the self-objectivation of human reason or the universal activity mankind has devised for itself in order to make

\footnotetext{
${ }^{35}$ Hence there is no conflict between the historical critical Besinnung and transcendental phenomenology since transcendental phenomenology is a separate, well-defined method that is used within Besinnung to make it radical (cf. Carr 1991).
} 
possible a truly satisfying life, an individual and social life of practical reason. The belief that science leads to wisdom-to an actually rational self-cognition and cognition of the world and God, and, by means of such cognition, to a life somehow to be shaped closer to perfection, a life truly worth living, a life of 'happiness', contentment, well-being, or the like-this great belief, once the substitute for religious belief, has (at least in wide circles) lost its force. Thus men live entirely in a world that has become unintelligible, in which they ask in vain for the wherefore, the sense, which was once so doubtless and accepted by the understanding, as well as by the will. (FTL, 5). ${ }^{6}$

\section{Conclusion}

In this paper I have tried to show how Husserl approaches exact science as a practice with a long tradition, developing towards the realization of its final sense. Husserl's method, radical Besinnung, aims to uncover this final sense. Through transcendental phenomenological investigations the presuppositions, evidences, and the basic concepts of exact sciences are examined. The outcome of radical Besinnung is criticism of existing practices. This method is also applied in The Crisis, where Husserl examines the sense of modern rationality as embodied by the sciences generally and as exemplified by the mathematization of the sciences. In FTL as well as in The Crisis radical Besinnung becomes a general framework within which transcendental phenomenological descriptions acquire a critical function. The task of the philosopher, for Husserl, is to engage in such radical Besinnung of the goal directed activities, so

\footnotetext{
36 "Die gegenwärtige Lage der europäischen Wissenschaften nötigt zu radikalen Besinnungen. Sie haben im Grunde den großen Glauben an sich selbst, an ihre absolute Bedeutung verloren. Der moderne Mensch von heute sieht nicht wie der 'moderne' der Aufklärungsepoche in der Wissenschaft und der durch sie geformten neuen Kultur die Selbstobjektivierung der menschlichen Vernunft oder die universale Funktion, die die Menschheit sich geschaffen hat, um sich ein wahrhaft befriedigendes Leben, ein individuelles und soziales Leben aus praktischer Vernunft zu ermöglichen. Dieser große Glaube, dereinst der Ersatz für den religiösen Glauben, der Glaube, daß Wissenschaft zur Weisheit führe - zu einer wirklich rationalen Selbsterkenntnis, Welt- und Gotterkenntnis, durch sie hindurch zu einem wie immer vollkommener zu gestaltenden, einem wahrhaft lebenswerten Leben in 'Glück,' Zufriedenheit, Wohlfahrt usw. -, hat jedenfalls in weiten Kreisen seine Kraft verloren. Man lebt so überhaupt in einer unverständlich gewordenen Welt, in der man vergeblich nach dem Wozu, dem dereinst so zweifellosen, vom Verstand wie vom Willen anerkannten Sinn fragt. "(FTL 9).
} 
as to ensure that the goals are possible, that they are not confused and conflated, and that the concepts we use are in line with our normative aims. The framework of radical Besinnung thus makes the implicit critical aims of the phenomenological explorations explicit. The phenomenologist's responsibility is thus not only to engage in constitutive analyses for her own sake but for a higher purpose-to use her results to reflect on the senses of the practices around her.

Conflict of interest statement: There is no conflict of interest.

\section{References:}

FTL Husserl, Edmund. (1974). Formale und transzendentale Logik: Versuch einer Kritik der logischen Vernunft (1929). Husserliana XVII. Ed. P. Janssen. The Hague: Martinus Nijhoff.

English translation: Formal and Transcendental Logic, translated by Dorion Cairns. Martinus Nijhoff. The Hague. 1969.

Hua 1-42 Edmund Husserl. Gesammelte Werke (Husserliana) (I-XLII). The Hague: Martinus Nijhoff, 1950-1987/Dordrecht: Kluwer Academic Publishers, 19882004/Dordrecht: Springer, 2004-2014.

Crisis Husserl, Edmund (1976). Die Krisis der europäischen Wissenschaften und die transzendentale Phänomenologie: Eine Einleitung in die phänomenologische Philosophie (1936). Husserliana VI. Ed. W. Biemel. The Hague: Martinus Nijhoff. English translation: The Crisis of European Sciences and Transcendental Phenomenology. An Introduction to Phenomenological Philosophy. Translated by David Carr. Evanston: Northwestern University Press, 1970.

Becker, Oskar. (1973) Mathematische Existenz, Untersuchungen zur Logik und Ontologie mathematischer Phänomene. 2., unveränderte Auflage. Tübingen, Max Niemeyer Verlag, [1927].

Carr, David. (1991). Time, narrative, history. Bloomington, Indiana University Press [1986]

Da Silva, Jairo José (2017). Mathematics and Its Applications. A Transcendental-Idealist Perspective. Synthese Library 385. Studies in Epistemology, Logic, Methodology, and Philosophy of Science. Springer

Dodd, James. (2004). Crisis and Reflection, an Essay on Husserl's Crisis of the European Sciences. Dordrecht: Springer.

Ewald, William (1996). From Kant to Hilbert: A Source Book in the Foundations of Mathematics. Vol II. Oxford: Clarendon Press. 
Hartimo, Mirja (2018). Husserl's Scientific Context 1917-1938, a look into Husserl's private library. Forthcoming in The New Yearbook for Phenomenology and Phenomenological Philosophy.

Hartimo, Mirja (2017). Husserl and Hilbert. Essays on Husserl's Logic and Philosophy of Mathematics, edited by Stefania Centrone, Synthese Library. Springer. 245 - 263.

Hartimo, Mirja (2016). Husserl on Completeness, Definitely. Synthese, 2016. DOI: 10.1007/s11229-016-1278-7.

Heffernan, George (unpublished manuscript). "Concordance to Husserl's Use of the Term Besinnung"

Heffernan, George (1989). Isagoge in die phänomenologische Apophantik. Eine Einführung in die phänomenologische Urteilslogik durch die Auslegung des Textes der Formalen und transzendentalen Logik von Edmund Husserl. Dordrecht, Boston, London: Kluwer Academic Publishers.

Hilbert, David (1922). Neubegründung der Mathematik. Hamburg: Verlag des mathematischen Seminars, 1922. Translation in Ewald, William (1996). From Kant to Hilbert: A Source Book in the Foundations of Mathematics. Vol II. Oxford: Clarendon Press: 1117-1134.

Kern, Iso (1976). The Three Ways to the Transcendental Phenomenological Reduction in the Philosophy of Edmund Husserl. Translated by F. Elliston and P. Mc Cormick. In Elliston and McCormick (eds): Husserl, Expositions and Appraisals. Notre Dame, London: University of Notre Dame Press: 126-149. [1962]

Klev, Ansten (2017). Husserl's Logical Grammar. History and Philosophy of Logic. DOI: 10.1080/01445340.2017.1399782

Mancosu, Paolo (2010). The Adventure of Reason. Interplay between Philosophy of Mathematics and Mathematical Logic 1900-1940. Oxford: Oxford University Press.

Moran, Dermot (2012). Husserl's Crisis of the European Sciences and Transcendental Phenomenology: An Introduction. Cambridge University Press

Rouse, Joseph (2002). How Scientific Practices Matter: Reclaiming Philosophical Naturalism. Chicago: University of Chicago Press.

Schuhmann, Karl (1977). Husserl-Chronik, Denk-und Lebensweg Edmund Husserls. The Hague: Martinus Nijhoff.

Steinbock, Anthony (1995). Home and Beyond. Generative Phenomenology After Husserl. Evanston, Ill: Northwestern University Press.

Weyl, Hermann (1925). ”Die heutige Erkenntnislage in der Mathematik.” Symposion, Philosophische Zeitschrift für Forschung und Aussprache 1 (1). 1-32.

Weyl Hermann (1926). Philosophie der Mathematik und Naturwissenschaft. München: Oldenburg.

Weyl, Hermann (2009) [1949]. Philosophy of Mathematics and Natural Science. Princeton, New Jersey; Woorstock, Oxfordshire: Princeton University Press.

Wimsatt, William C. (2007). Re-engineering philosophy for limited beings: piecewise approximations to reality. Cambridge, London: Harvard University Press. 
von Wright, G. H. (1963). Norm and Action. Routledge and Kegan Paul, London. [1961] 